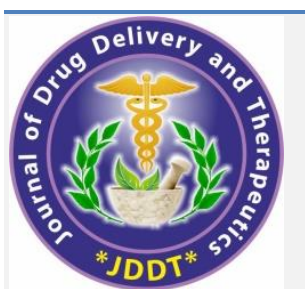

Open Access Full Text Article

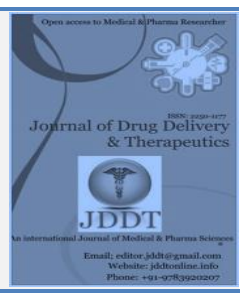

\title{
An overview of green synthesis mediated metal nanoparticles preparation and its scale up opportunities
}

\author{
Anupama Singh (D), Madhavi BLR (D)*, Nithin Sagar M N (D) \\ Department of Pharmaceutics, Acharya \& BM Reddy College of Pharmacy, Soldevanahalli, Hesergatta Road, Benagluru-560107, Karnataka, India
}

\section{Article Info:}

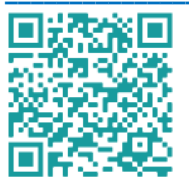

Article History:

Received 19 September 2021 Reviewed 26 October 2021 Accepted 08 November 2021 Published 15 November 2021

\section{Cite this article as:}

Singh A, Madhavi BLR, Nithin Sagar MN, An overview of green synthesis mediated metal nanoparticles preparation and its scale up opportunities, Journal of Drug Delivery and Therapeutics. 2021; 11(6):304-314

DOI: http://dx.doi.org/10.22270/jddt.v11i6.5082

\section{Abstract}

Nanoparticles in different field of science have a wide range of utility. They come in different forms. Among these, metal nanoparticles (MNP) have become an emerging tool for diagnostic as well as for therapeutic purposes. Metal nanoparticles are nano-sized particles made up of inorganic metals or their metal oxides. Various methods are available for the preparation/production of metal nanoparticles. In addition to the existing physical and chemical methods, green synthesis is an area that has drawn the attention of researchers in the decade and continues to be a potential area of research. The following review introduces about metal nanoparticles and discusses in details about the plant extract mediated metal nanoparticles synthesis, the principle of metal nanoparticle formation, various process parameters that are important for its synthesis, characterization of metal nanoparticles and the scope for commercialization are elaborated. Metal nanoparticles at research, employing plant extract mediated green synthesis have been extensively reviewed. This review tries to bring into light the feasibility of commercializing the green synthesis by using plant extracts.

Keywords: Green synthesis; Plant extract; One-step synthesis; Characterization; Process parameters; Scale-up

\footnotetext{
*Address for Correspondence:
}

Dr. Madhavi BLR, Department of Pharmaceutics, Acharya \& BM Reddy College of Pharmacy, Soldevanahalli, Hesergatta Road, Benagluru-560107, Karnataka, India

ORCID ID: https://orcid.org/0000-0001-6004-0045

\section{Introduction}

Nano-medication is the field of science which combines nanotechnology and the delivery of drugs or medicines 1 . Nanotechnology is the science and engineering involved in the design, synthesis, characterization, and application of materials of small functional organized entities, with at least one dimension being in a nanometer scale or one billionth of a meter ${ }^{2}$. The nanoparticles serve as an important tool for better delivery of cutting edge treatment like genes, proteins, and other therapeutic advancements. They not only benefit therapeutically but also serve in diagnosis 3,4 . There are various types of nano-medicines available for therapy like liposomes, phytosomes, microparticles, nanoparticles, quantumdots, carbon nanotubes, metal nanoparticle, transfereosomes, ethosomes, colloidomes, coated liposomes, etc. Currently, metal nanoparticles are gaining much more importance 5 .

Metals are the most widely recognized materials utilized in the everyday engineering field ${ }^{6}$. They have their own characteristics of ductability, malleability and are good conductors of heat and electricity. They are strong due to their high inter-atomic bonds 7. Metals have unique properties for studying their microstructure by various techniques like scanning electron microscopy (SEM), secondary ion mass spectroscopy (SIMS), X-ray Photoelectron Spectroscopy (XPS) 6 . In the health scenario, metals are essential for our body as trace elements and micronutrients viz. iron a significant factor for hemoglobin; copper as a neurotransmitter, magnesium and zinc as enzyme co factors and so forth ${ }^{8}$. As a result of their physicochemical characteristics and physiological essentiality, metals are now being employed and explored as an avenue for therapy and drug delivery ${ }^{9}$.

Metal nanoparticles (MNP) are colloidal particles of metals like titanium, zinc, silver, gold, copper, platinum, etc., in the size range of 1-100 $\mathrm{nm}{ }^{10}$. The MNP have a high surface area to volume ratio 10 which helps in the addition of several functional groups like ligands, antibodies, and genes providing better targeting ability to those molecules. The surface properties of metals such as plasmon excitation, dielectric constant, optical properties, and others show a tremendous difference due to their conversion from a macro to a nano-size which makes them ideal for targeting therapeutic agents. These are having greater capability to carry a high dose of drug and increase its circulatory half-life 10,11 .

MNP have a huge demand owing to their immense utility ranging from catalysts 12 , chemical sensors 13 , electronic 
components 14 , medical diagnostic imaging, pharmaceutical products, and medical treatment protocols ${ }^{15}$. For e.g.: Gold nanoparticles (NP) are utilized in biomedical application, disease diagnosis, and pharmaceutical applications like targeting anticancer drugs ${ }^{16}$. Silver NP exhibit the property of anti-inflammatory and anti-bacterial action and are frequently utilized for wound healing purposes 17,18 . Other MNP include copper, zinc, selenium which is employed for functions such as anti-microbial activity ${ }^{19}$, applications in cosmetic formulations, etc. 20 .

These are having potential therapeutic applicability; various literatures have been reported on green synthesis and its vast applications. But there is a lack of data on the scale-up feasibility for plant-mediated green synthesis. So this review tries to bring upon some of the possible equipment's that can help in widening the opportunities.

\section{Production of MNP}

MNP are employed in many industries like electronics, biomedical engineering, magnetic imaging, and paints 14, 15, 21 . They are thus being produced on a commercial scale and the production methods may be classified into

\subsection{Top-down method 22 and}

\subsection{Bottom-up method 22 .}

These methods may further be segregated based on the process involved into physical or chemical processes ${ }^{23}$.

The top down method is based upon breaking big materials into small nano-sized materials 24 . It mainly includes mechanical attrition, nano-lithiography 25 , chemical etching, sputtering, thermal and laser ablation while the bottom up increases the size by self-assembling the atoms into nanoscale particles 24. Bottom up methods include sol-gel process, electrochemical precipitation, laser pyrolysis, spray pyrolysis, vapor phase technique and liquid phase techniques 25 . For most of the metals like iron, gold, zinc oxide, silver and titanium oxide are produced preferably by employing liquid phase synthesis or vapor phase synthesis instead of milling or mechanical grinding. Whereas in the case of, silver and gold, liquid phase precipitation is preferred over vapor phase synthesis due to the ease of control over particle size. ${ }^{26}$.

When commercialization is concerned, not only production capacity but other factors need to be considered. Those factors include consistency in product quality and costs related to raw materials, operation, yield, capital equipment, safety, waste disposal and environmental issues such as carbon emission. The reason why only a few types of nanoparticulate materials are used in the current consumer products is due to the technical and commercial restrictions on large scale production ${ }^{27}$. Secondly, chemical processes like electrodeposition, laser ablation, chemical vapor deposition etc., are associated with certain demerits like toxicity due to the use of chemical agents like sodium borohydride, hydrazine hydrate even the use of toxic chemical gas as a precursor in the chemical vapor disposition method; high energy demand which is mostly seen in case of ball milling; lengthy reaction time, and non-eco-friendly byproducts. This hauls the enthusiasm of researchers to explore new methods for the manufacture of MNP. One of the upcoming avenues is the green synthesis ${ }^{28}$.

\section{Green synthesis}

MNP preparation by the green synthesis approach uses biological resources i.e. microorganisms 29 , and plants 30 . Green synthesis is promising on an account of a less labor- intensive and easy method of MNP formation. This synthesis does not involve any use of harmful or toxic chemicals and yields no hazardous by-products 31 . The methods of production may be segregated based on the biological source employed as given below 32

\subsection{Green synthesis via micro-organisms}

Microbes are used in the production of MNP 33. Bacteria 34 , fungi 35 , yeast 36 , actinomycetes 37 , and algae 38 have been studied for the same. The development of MNP by means of microorganisms is challenging because of certain factors like a long processing time, availability of specific strains microorganisms, contamination issues requiring extra care during media preparation and culturing, isolation, and culture maintenance ${ }^{39}$.

\subsection{Green synthesis via Plants}

Plants are the best gift from nature 39. Plants absorb substances from the soil and this include uptake of minerals. Plants are reported to take up heavy metals. This phytoremediation employs to detoxify the environment 40,41 . As plants possess hyper-accumulation and can even reduce inorganic metal ions to MNP in a single-step synthesis 39,41 . Plants have bountiful phytochemicals like alkaloids, alcohols, flavonoids, and so on, which are obtained from different parts like roots, stems, leaves, fruits, flowers, and seeds. These phytochemicals aid in nanoparticle formation ${ }^{42}$. The nanoparticles acquired from the plant can be altered into various shapes and sizes with alluring morphological needs 43 .

Plant based synthesis can be performed via intra-cellular, extracellular and through phytochemical mediation. In the case of intracellular MNP synthesis, living plant cell broth is incubated with metal salt solution leading to its reducing to MNP. In extracellular synthesis and phytochemical mediated synthesis, aqueous metal salt solution is mixed with a plant extract or a specific phytochemical respectively 42,44 .

Plant extracts are non-toxic, biocompatible to human cells 45 , and they are also good in drug delivery, even in diagnostic fields, etc. Moreover, more stable MNP are formed by using plant extracts than the microbial method ${ }^{39}$.

A simple pictorial representation of plant extract mediated MNP synthesis is shown in Figure 1. Plant extract mediated green synthesis is a one step process for synthesis of MNP because the phytochemicals themselves act as reducing as well as stabilizing agents.

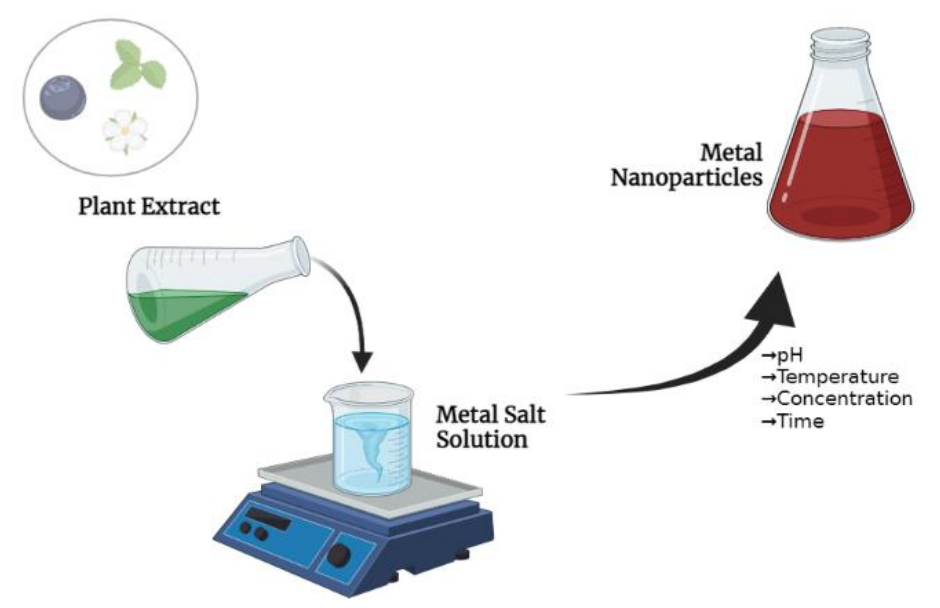

Figure 1: One step process for plant extract mediated green synthesis of MNP. 


\section{Lab scale synthesis}

The lab scale synthesis is mainly opted by researchers due to certain advantages. Synthesis in the lab has a very simple procedure requiring the use of minimal equipment and process parameters ${ }^{46}$. The lab process can be explained by three major steps 47 :

\subsection{Preparation of plant extract}

\subsection{Preparation of Metal salt solution}

\subsection{Formulation of MNP}

4.1. Preparation of plant extract: The extract is prepared by choosing the desired plant part (leaves ${ }^{48}$, seed 49 , flower 50 , root 51 , stem 52 and fruits ${ }^{53}$ ) or phytochemicals 54,55 that are required for reduction of the metal ion. The collected material is washed properly and air-dried. After drying, the plant material is milled into finer pieces 56 , the phytochemicals for reduction are extracted either in organic 57,58 /aqueous media 59, 60,61. The most common extraction method employed is decoction 62 . Other methods like maceration ${ }^{63}$, soxhlation 57 , etc. have also been reported. The extract is filtered or centrifuged to remove unwanted debris and stored at $4^{\circ} \mathrm{C}$ for future use $59-61,64$.

4.2. Preparation of metal salt solution: The metal precursor is a metal salt. A solution is made by taking a required quantity of metal salt and dissolving it in water. This serves as the source of the metal ion. One of the important factors for MNP synthesis is the concentration of the metal salt solution, which mainly varies from $1 \mathrm{mM}$ to $5 \mathrm{mM}$ 65. As mentioned in Fig 1 . some metal salts include silver nitrate, zinc oxide, copper sulfate, etc.

4.3. Green synthesis of MNP: In this step the metal salt solution is mixed with plant extract to yield metal nanoparticles ${ }^{48-65}$. The formation of MNP is indicated by visual perception. Change of color in the reaction mixture indicates formation of MNP 66. The color varies for different metals. For silver the color change occurs from colorless to brown or reddish-brown ${ }^{67}$; for gold the color changes from yellow to reddish shade 68 or sometimes in violet color 69; Likewise for copper (precursor copper sulfate) the color changes from blue to dark brown 70 .

\section{Mechanism of MNP formation by plant extract mediated green synthesis}

The proper mechanism for MNP formation is unclear yet but several hypotheses have been postulated ${ }^{71}$. Plant extracts, due to the presence of various phytochemicals serve as a good reducing agents as well as a stabilizing agents for NP preparation. Bioactive molecules like flavonoids, alkaloids, saponins, steroids, terpenoids, and tannins, etc. reduce metal ions into metals and then stabilize them in the colloidal size range 72 .

The mechanism of MNP formation may be complex to understand due to the presence of a large number of phytochemicals in the extract having various reactive moieties like aldehyde, ketones, carboxyl, hydroxyl, etc. 73 . MNP formation by plant extract mediated green synthesis is a bottom up approach and can be divided into three phases 74:

\subsection{Activation phase}

5.2. Growth phase

5.3. Termination phase.
In the activation phase, the metal salt solution is reduced into metal ions via phytochemical constituents. The MNP formation rate at this phase is slow as it primarily involves the reduction of aqueous metal ion in mono or divalent oxidation state to neutral metal atoms $39,74,75$. Next, nucleation of metal atoms occur leading to the formation of particles increased size range than the atomic level. The metal atoms coalesce to give different morphological shapes like spheres, triangles, hexagons, pentagons, etc 39,74 . The bioactive molecules like flavonoids, terpenoids, proteins, polyphenols, etc interact with the aggregated metal atoms and get adsorbed onto the surface due to the $\pi$ electrons interactions ${ }^{74}$. The continuous growth phase emerges to be with improved thermodynamic stability of nanoparticles but an increase in the nucleation phase causes aggregation of nanoparticles that distorts their morphology. The last step in the synthesis is the termination phase, where capping of active molecules onto the surface of the metals provides a steric hindrance that limits particle aggregation thereby providing a stable morphology and size in the nano-range thus leading to formation of stable MNP ${ }^{74}$.

The reaction mixture is centrifuged to yield the MNP which sediments. The supernatant is decanted and the sediment is re-dispersed in deionized/distilled water to remove impurities ${ }^{76}$. Figure. 2 represents the mechanism of formation of MNP via green synthesis from plant extract.

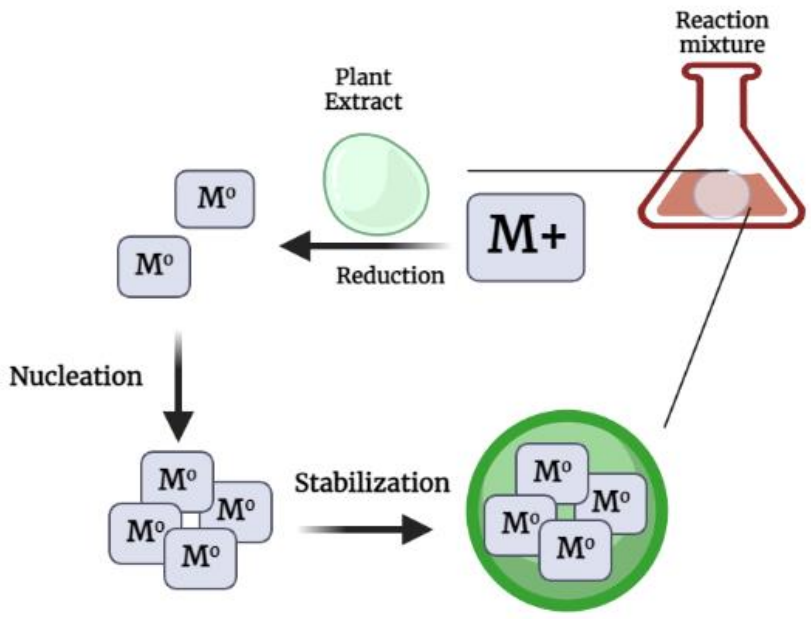

Figure 2: Mechanism of MNP formation by plant extract mediated green synthesis.

\section{Analytical methods employed}

Analytical methods are employed in the plant extract mediated green synthesis are: phytochemical screening of the plant extract and for the characterization of MNP 77 .

\subsection{Screening of Plant Extract:}

As discussed in the principle of MNP formation by plant extract mediated green synthesis that many phytochemicals are involved 72 . Screening of the extract has to be done to identify the presence of the desirable phytochemicals in the extract. Wet lab methods are used for qualitative study of the extract. Some chemical tests include ferric chloride test for phenolic compounds, Mayer's test for alkaloids, Fehling's test for glycoside, Liebermann-Burchard test for terpenoids, Lead-acetate test for tannins, Sulphuric acid test for flavonoids, etc $78,79,80$. Instrumental methods of analysis include chromatography techniques like Gas Chromatography (GC), High Performance Liquid Chromatography (HPLC), Thin Layer Chromatography (TLC) etc and Fourier Transform Infrared (FTIR) spectroscopic techniques $78,79,81$. 


\subsection{Characterization of MNP}

Upon completion of green synthesis process, the MNP are characterized for size, shape, yield, and dispersity of the particles. The various characterization techniques include UV-visible spectroscopy (UV-vis) for identification, characterization, and analysis; Dynamic Light Scattering (DLS) for the surface charge, size distribution, and quality; Atomic Force Microscopy (AFM) for surface characterization at the atomic scale; Scanning Electron Microscope (SEM) \& Transmission Electron Microscopy (TEM) are for surface and morphology characteristics; X-Ray Diffraction (XRD) for crystal structure; FTIR for identification of functional groups present and groups which stabilized the compound; zeta sizer for determination of indirect surface charge of the nanoparticles; Auger Electron Microscopy (AEM) for primary surface analysis; Inductively Coupled Plasma-optical Emission Spectroscopy (ICP-OES) for optical properties; Raman Spectroscopy and Energy Dispersive Spectroscopy
(EDS) for elemental composition [82,83,84].Among them, microscopic techniques are known to be direct techniques for characterizing the nanoparticles from their image while the spectroscopy techniques include the indirect method of collecting data about the composition, crystal phase, structure, and properties of nanoparticles. Most reported work on MNP green synthesis includes commonly used techniques which are UV, FTIR, ZETASIZER, SEM \& TEM 82,84 .

\section{Process parameters for plant extract mediated green synthesis}

The synthesis involves the use of metallic salts of metals like copper, zinc, iron, silver, gold, etc combining with the plant extract giving rise to MNP. The formation and morphology of nanoparticles differs according to the process parameters. Figure 3 indicates an overview of the process and parameters involved.

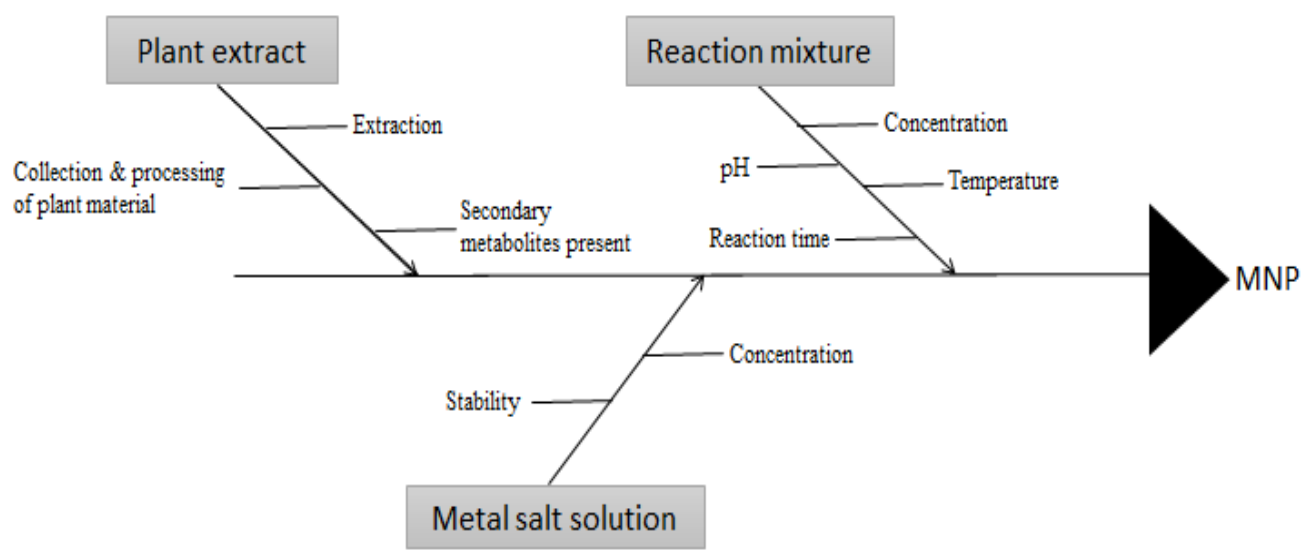

Figure 3: Process parameters in the synthesis of plant extract mediated green synthesis.

Some process parameters include:

\subsection{Collection \& processing of plant material:}

Presence of desirable phytochemicals is the pre-requisite for the MNP formation. The phytochemical constituents are dependent on the source of plant (wild/cultivated, geographical location), collection (season, method), processing (washing, drying, milling, etc.). The collection and processing of plant material if not done in standardized manner, may lead to low yield of phytochemicals which effects MNP formation 78 .

\subsection{Extraction method:}

For green synthesis, water is the commonly employed solvent to prepare the plant extract. Sometimes organic solvent like ethanol is also used. Phytochemical extraction may be carried out by decoction, maceration, soxhlation, etc 86. The extraction method should ensure stability of the desired phytochemicals.

\subsection{Phytochemical content:}

There are many phytochemical constituents like flavonoids, polyphenols, terpenoids, and enzymes, etc. which not only contribute to the formation of nanoparticles but also aid in the stabilization of MNP. Additionally, they also impart pharmacological activity ${ }^{87}$. Some of the possible phytochemicals responsible are listed below:

Flavonoids are polyhydroxy phenolic compounds which undergo tautomeric transformation from enol to keto form, releasing reactive hydrogen thereby contributing for the reduction of metal $31,44,88-91$.

Terpenoids belongs to hydrocarbon group. It contains alcohols, ketones, aldehydes, and lactones group which are responsible for reduction as well as stabilization of MNP. Terpenoids can easily get adsorbed onto the surface by interaction of $\pi$ electrons and carbonyl groups 31,44,88-91.

Sugars are chemically Carbon, Hydrogen and Oxygen. There are different types of sugars - monosaccharides (simple sugar), disaccharides (complex sugar) and polysaccharides. It is seen that monosaccharides contain linear chain with aldehyde group that helps in reducing metal easily while disaccharides and polysaccharides reducing ability depends upon the opening of the chain giving ability to access the aldehyde group 31,44, 88-91.

Proteins consist of amino acid. It is seen that amino acids like tyrosine, arginine, and lysine have ability to reduce metal ions 31,44,88-91.

\subsection{Stability of components:}

Stability of the reaction components is imperative for MNP synthesis. Metal salt solutions are prone to degradation. It is seen that silver salt solution degrades easily by photolytic degradation and hence precaution is to be taken during processing. ${ }^{92}$. Similarly, the plant extracts too should be ensured to be stable and not be contaminated. The extracts are generally kept in cold condition $\left(4^{\circ} \mathrm{C}\right)$ to prevent microbial contamination and chemical degradation of phytoactives. 


\section{5. $\mathrm{pH}$ :}

The $\mathrm{pH}$ of the medium plays an essential role in the formation, shape and size of the nanoparticles. Alteration of $\mathrm{pH}$ affects the charge alteration in the plant metabolite thereby influencing the reduction and chelating of metal ions in the process. The ranges reported for $\mathrm{pH}$ maintenance of the metal solution / extract / reaction mixture include from $\mathrm{pH} 3-12$.It is seen that increase in the $\mathrm{pH}$ generally above 7 causes the formation of smaller and spherical nanoparticles

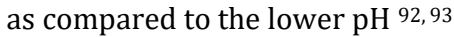

Gurubasavara et al ${ }^{94}$ reported that the silver NP formed in alkaline $\mathrm{pH}$ is more stable than those in acidic medium. The $\mathrm{Ph}$ also influenced the size of silver NP where size is inversely proportional to the $\mathrm{pH}$ of the reaction mixture. They found that the formed size is uniform and well distributed at $\mathrm{pH} 9$.

While in his research Ashwani Kumar Singh 95 clearly demonstrated the difference in shape and size of MNP by varying the $\mathrm{pH}$. The gold nanoparticles mediated by black cardamom extract were synthesized employing solutions of different $\mathrm{pH}$. It was observed that at $\mathrm{pH} 3$ the particles had a spherical flower shaped morphology with a particle size of $90-100 \mathrm{~nm}$ and at $\mathrm{pH} 7$ the particles were almost spherical in shape with an average size $20-40 \mathrm{~nm}$.

\subsection{Temperature:}

The reaction temperature for any synthesis is important to give the desired product according to the quality and quantity. Here, the temperature has an impact on the size, shape, and yield of nanoparticles. It is generally seen that high temperature boosts the nucleation rate thereby leading to the production of crystalline nanoparticles. Basically, the temperature and size of nanoparticles are seen to be inversely proportional to each other 92,93 .

Bo Rao 96 looked into the green synthesis of silver nanoparticles with Eriobotrya japonica and studied the effect of increasing the temperature upon the particles. It showed when the temperature has been increased from $25^{\circ} \mathrm{C}$ to 80 ${ }^{\circ} \mathrm{C}$ the particle size decreased from $76.10 \mathrm{~nm}-54.47 \mathrm{~nm}$. At higher temperature, the particles were found to have uniformity in their size and were having high yield. Likewise, Husan ${ }^{97}$ got the outcome of increasing the temperature is an increase in the reaction rate. In this work different temperature condition was maintained i.e. $25^{\circ} \mathrm{C}, 35$ ${ }^{\circ} \mathrm{C}$ and $45^{\circ} \mathrm{C}$, which showed that at $45^{\circ} \mathrm{C}$ the absorbance, was more, marking the outcome of nanoparticles.

\subsection{Reactant concentration:}

The reactant concentration of metal salt, as well as the plant extracts, has a great impact on the formation of nanoparticles. A study by Roya et al. ${ }^{98}$ proclaimed that concentration plays an important role in both the reactant. It is seen that the synthesis of nanoparticles increases with an increasing amount of concentration. The plant extract addition increases the reaction due to an increase in the functional group reacting with the silver ions, while the addition of silver ions increases the reducing group. The reaction increases up to a certain level of concentration and declines when it exceeds the optimal concentration 92,93 .

\subsection{Reaction time:}

Reaction time influences the proper synthesis and stability of nanoparticles. The change in the color of the medium is indicative of the change in the surface resonance. When the color remains constant for a long time, indicates that the MNP are completely synthesized 92, 93. The study by Sekhar et al ${ }^{99}$ showed that reaction time is an important factor. In this case, the color change occurred in $8 \mathrm{~min}$ from yellow to light red in the reaction medium but the actual reaction continued till $60 \mathrm{~min}$ with the color change to intense wine red. It was seen that at 5 min there were no Surface Plasma Resonance (SPR) reading but after $10 \mathrm{~min}$ the SPR band increased and became constant at $60 \mathrm{~min}$. The UV study showed an increase in absorbance from $5 \mathrm{~min}$ till $60 \mathrm{~min}$ and then getting it in constant phase after the final reduction and formation of gold nanoparticles with an average particle size of $55.22 \pm 42.86 \mathrm{~nm}$.

\subsection{Product recovery}

The unreacted extract components need to be discarded and free flowing powder NP needs to be collected for further characterizations. The MNP formed via plant extract mediated synthesis are more stable therefore they are mainly centrifuged at $10,000 \mathrm{rpm}$ for $15 \mathrm{~min}$ so that all particles how much small, it may be collected. The NPs collected are then rinsed off with water thrice to remove any stuck components within them. The free flowing powder is collected by undergoing a lyophilization process.

\section{Scope for scale up}

Plant mediated nanotechnology is novel approach, environmentally as well as pharmacologically. The green synthesis can be easily scaled up 100 as the machinery which may be employed is most commonly found in herbal, ayurvedic and pharmaceutical industry. Table 1 given below summarizes the possible unit operations that may be involved in plant extract mediated green synthesis of MNP and the availability of machinery for the same.

Table 1: Possible unit operations for plant extract mediated green synthesis of MNP.

\begin{tabular}{|l|l|}
\hline UNIT OPERATION & MACHINERY EMPLOYED101 \\
\hline Plant material and processing & $\begin{array}{l}\text { Milling- Hammer mill, roller flake, seed grater etc. } \\
\text { Phytochemical screening- LCMS-MS, Super Critical Fluid Chromatography etc. }\end{array}$ \\
\hline $\begin{array}{l}\text { Plant extraction } \\
\text { Synthesis salt solution and Green }\end{array}$ & $\begin{array}{l}\text { Principle equipment- distillation, soxhalation in Hydro distillation unit Buchi Extraction } \\
\text { system B-811, Buchi Rota vapors, Phase exchange-liquid liquid extraction facility etc. }\end{array}$ \\
\hline Product collection & Common equipment- centrifugation, lyophilizing . \\
\hline
\end{tabular}




\section{Recent works}

The popularity of green synthesis is reflected in the quantum of work being undertaken. Numerous works have been carried out in this field using different standardization
Journal of Drug Delivery \& Therapeutics. 2021; 11(6):304-314 techniques. Few of the latest research works are stated in the table 2 given below.

Table 2: Recent works on the preparation of metal nanoparticles by green synthesis along with the probable reducing groups responsible in the synthesis

\begin{tabular}{|c|c|c|c|c|c|c|}
\hline $\begin{array}{l}\text { Sl } \\
\text { no }\end{array}$ & Metal & Plant & Part used & Phytoconstituents & Applications & Ref \\
\hline 1. & Gold & Curcuma kwangsiensis & Leaves & $\begin{array}{l}\text { Flavonoids, alkaloids, } \\
\text { terpenoids. }\end{array}$ & $\begin{array}{l}\text { Cytotoxicity specifically } \\
\text { for ovarian cancer. }\end{array}$ & 102 \\
\hline 2. & Gold & Cannabis sativa & Leaves & $\delta 9$-tetrahydrocannabinol & Leukaemia & 103 \\
\hline 3. & Gold & Allium sativum & Leaves & $\begin{array}{l}\text { Methyl methane sulfinate, } \\
\text { Dimethyl sulphide, Methyl } \\
\text { propyl disulphide }\end{array}$ & Cytotoxicity & 104 \\
\hline 4. & Gold & $\begin{array}{l}\text { Curcuma } \\
\text { pseudomontana }\end{array}$ & Rhizomes & Flavonoids & $\begin{array}{l}\text { Antibacterial, anti- } \\
\text { inflammatory }\end{array}$ & 105 \\
\hline 5. & Gold & Mentha longifolia & Leaves & Phenolic compounds & Breast cancer & 106 \\
\hline 6. & Silver & Nigella sativa & Seeds & Fatty acids and volatile oils & Anti-diabetic & 107 \\
\hline 7. & Silver & Phyllanthus emblica & Fruits & Polyphenols & Reducing agent & 108 \\
\hline 8. & Silver & Terminalia bellirica & Fruits & Ellagitannins & Purification of water & 109 \\
\hline 9. & Silver & Sambucus nigra & Fruits & Polyphenols & Treat oral dysplasia & 110 \\
\hline 10. & Silver & Zingiber officinale & Leaves & Gingerol & Anti-oxidant & 111 \\
\hline 11. & Copper & Citrus sinensis & Fruits & Terpenes & Antibacterial property & 112 \\
\hline 12. & Copper & Psidium guajava & Leaves & Terpenoids & Antibacterial property & 113 \\
\hline 13. & Copper & Camellia sinensis & Leaves & Alkaloids and flavonoids & $\begin{array}{l}\text { Cytotoxicity and } \\
\text { antioxidant }\end{array}$ & 114 \\
\hline 14. & Copper & Syzgium cumini & $\begin{array}{l}\text { Flower } \\
\text { and seeds }\end{array}$ & Anthocyanins and alkaloids & Antimicrobial property & 115 \\
\hline 15. & Copper & Eucaplyptus globulus & Leaves & Phenols & Antimicrobial activity & 116 \\
\hline 16. & Zinc & Alchornea laxiflora & Leaves & Quercetin & Catalytic activity & 117 \\
\hline 17. & Zinc & Alhagi maurorum & Leaves & Nonacosane & Antioxidant & 118 \\
\hline 18. & Zinc & $\begin{array}{l}\text { Gynostemma } \\
\text { pentaphyllum }\end{array}$ & Leaves & Saponins and flavonoids & Antitoxicity agent & 119 \\
\hline 19. & Zinc & Salvia officinalis & Leaves & Flavonoids and phenols & Antifungal activity & 120 \\
\hline 20. & Zinc & Raphanus sativus & Leaves & Flavonoids and alkaloids & $\begin{array}{l}\text { Antioxidant and } \\
\text { antitumor }\end{array}$ & 121 \\
\hline 21. & Selenium & Zingiber officianle & Rhizomes & Gingerol & Antimicrobial & 122 \\
\hline 22. & Selenium & Azadirachta indica & Leaves & Azadirachitin and quercetin & Antimicrobial activity & 123 \\
\hline 23. & Iron & Zingiber officinale & Rhizomes & Gingerol & Antibacterial activity & 124 \\
\hline 24. & Iron & Chlorophytum comosum & Leaves & Saponins & Antibacterial activity & 125 \\
\hline 25. & Iron & Mikania mikrantha & Leaves & $\begin{array}{l}\text { Steroids, flavonoids and } \\
\text { terpenoids }\end{array}$ & Antibacterial activity & 126 \\
\hline
\end{tabular}




\section{Clinically approved MNP}

There are a few approved MNP which are shown in the table 3 below

Table 3: List of clinically approved MNP.

\begin{tabular}{|c|c|c|c|c|}
\hline Sl no. & Brand name & MNP & Clinical application & Refs \\
\hline 1 & Feraheme® & $\begin{array}{l}\text { Superparamagnetic iron oxide } \\
\text { nanoparticle (SPION) }\end{array}$ & Anemia in chronic kidney disease & 127 \\
\hline 2 & Ferinject ${ }^{\circledR}$ & Nanoparticles of ferric oxide & Iron deficiency anemia in chronic kidney disease & 127 \\
\hline 3 & NanoTherm $®$ & $\begin{array}{l}\text { Nanoparticles of } \\
\text { superparamagnetic iron oxide }\end{array}$ & Glioblastoma, prostate, pancreatic cancer & 127 \\
\hline 4 & Acticoat ${ }^{\circ}$ & Nanocrystalline silver & $\begin{array}{l}\text { Dressings for a range of wounds including burns, } \\
\text { bacterial infection }\end{array}$ & 128 \\
\hline 5 & SilvaSorb® & Nanosilver & $\begin{array}{l}\text { Wound dressings and cavity filler prevent } \\
\text { bacterial infection }\end{array}$ & 128 \\
\hline
\end{tabular}

\section{Conclusions}

Plant extract mediated green synthesis, as in understood from the review literature has gained importance and has also shown to be promising in terms of the pharmacological activity. The various process parameters determine MNP formation and clearly indicate that plant extract mediated green synthesis has tremendous potential for researcher in the role to streamline and validate the process. The yield of MNP from plant extract mediated green synthesis has not been highlighted much, which calls for attention. Literature also reveals that commercialization of plant extract mediated green synthesis of MNP is quite feasible.

Thus, conclusively this review shows that there is a scope for research and startups in the area of plant extract mediated green synthesis of MNP.

\section{Abbreviations}

MNP: Metal nanoparticles, NP: Nanoparticles, nm: nanometer, rpm: Revolution per minute, min: Minute.

\section{References}

[1] Soares S, Sousa J, Pais A, Vitorino C. Nanomedicine: principles, properties, and regulatory issues. Frontiers in chemistry. 2018 Aug 20;6:360. https://doi.org/10.3389/fchem.2018.00360

[2] Ventola CL. The nanomedicine revolution: part 1: emerging concepts. Pharmacy and Therapeutics. 2012 Sep;37(9):512. http://www.ncbi.nlm.nih.gov/pmc/articles/pmc3462600/

[3] Patra JK, Das G, Fraceto LF, Campos EV, del Pilar Rodriguez-Torres M, Acosta-Torres LS, Diaz-Torres LA, Grillo R, Swamy MK, Sharma S, Habtemariam S. Nano based drug delivery systems: recent developments and future prospects. Journal of nanobiotechnology. 2018 Dec;16(1):1-33.

[4] Parveen S, Misra R, Sahoo SK. Nanoparticles: a boon to drug delivery, therapeutics, diagnostics and imaging. Nanomedicine: Nanotechnology, Biology and Medicine. 2012 Feb 1;8(2):147-66. https://doi.org/10.1016/j.nano.2011.05.016

[5] Rout GK, Shin HS, Gouda S, Sahoo S, Das G, Fraceto LF, Patra JK. Current advances in nanocarriers for biomedical research and their applications. Artificial cells, nanomedicine, and biotechnology. $2018 \quad$ Nov 5;46(sup2):1053-62. https://doi.org/10.1080/21691401.2018.1478843

[6] KurzydŁowski KJ. Structure and properties of metals. ActaPhys Pol A. 1999;96(1):69-79.

[7] BBC. Metallic structure and bonding. Available from: https://www.bbc.co.uk/bitesize/guides/z9m6v9q/revision/2 (Accessed on 30th January,2021)
[8] Tsuzuki T. Commercial scale production of inorganic nanoparticles. International journal of nanotechnology. 2009 Jan 1;6(5-6):567-78. https://dx.doi.org/10.1504/IJNT.2009.024647

[9] Barui AK, Kotcherlakota R, Patra CR. Medicinal applications of metal nanoparticles. InMetal Nanoparticles: Synthesis and Applications in Pharmaceutical Sciences 2018 Jan 3 (pp. 101-153). Wiley. https://doi.org/10.1002/9783527807093.ch5

[10]Scientia ricerca. Biogenic-Biosynthesis Metallic nanoparticles(MNPs) for pharmacological, biomedical and environmental Nanobiotechnology Applications. Available from: https://scientiaricerca.com/srcops/SRCOPS-02-00038.php (Accessed on 20th February,2021)

[11]Akram M, Farooq QH, Shafiq MI, Awan AS. Synthesis and characterization of some important metal nanoparticles and their applications. SciInt (Lahore). 2016;28:4049-59.

[12] Narayan N, Meiyazhagan A, Vajtai R. Metal nanoparticles as green catalysts. Materials. 2019 Jan;12(21):3602. https://dx.doi.org/10.3390\%2Fma12213602

[13] Mandal R, Baranwal A, Srivastava A, Chandra P. Evolving trends in bio/chemical sensor fabrication incorporating bimetallic nanoparticles. Biosensors and Bioelectronics. 2018 Oct 15;117:546-61. https://doi.org/10.1016/j.bios.2018.06.039

[14] Nakamoto M. Microelectronics Packaging by Metal Nanoparticle Pastes. InNanoparticle Technology Handbook 2018 Jan 1 (pp. 647650). Elsevier. https://doi.org/10.1016/B978-0-444-641106.00053-6

[15]Klębowski B, Depciuch J, Parlińska-Wojtan M, Baran J. Applications of noble metal-based nanoparticles in medicine. International journal of molecular sciences. 2018 Dec;19(12):4031. https://doi.org/10.3390/ijms19124031

[16]Dupoint. Gold Nanoparticles- Properties, Application. AZO Nano 2013 April. Available from: https://www.azonano.com/article.aspx?ArticleID=3284 (Accessed on 21 $1^{\text {st }}$ February 2021).

[17]Selim HM, Mohamed DS, Eskander HM. Silver nanoparticles: synthesis, medical application, and toxicity effects. International Journal of Nanotechnology and Allied Sciences. 2017 Dec $13 ; 1(1): 45-53$.

[18]Xu L, Wang YY, Huang J, Chen CY, Wang ZX, Xie H. Silver nanoparticles: Synthesis, medical applications and biosafety. Theranostics. https://dx.doi.org/10.7150\%2Fthno.45413

[19]Sánchez-López E, Gomes D, Esteruelas G, Bonilla L, LopezMachado AL, Galindo R, Cano A, Espina M, Ettcheto M, Camins A, Silva AM. Metal-based nanoparticles as antimicrobial agents: an overview. Nanomaterials. $2020 \quad$ Feb;10(2):292. https://doi.org/10.3390/nano10020292 
Singh et al

[20]Niska K, Zielinska E, Radomski MW, Inkielewicz-Stepniak I. Metal nanoparticles in dermatology and cosmetology: Interactions with human skin cells. Chemico-biological interactions. 2018 Nov 1;295:38-51. https://doi.org/10.1016/j.cbi.2017.06.018

[21]DuPont. Titanium Oxide (Titania, TiO2) Nanoparticles Properties, Applications. AZoNano. 17 April 2021.Available from:https://www.azonano.com/article.aspx?ArticleID=4710\#: : text=Currently $\% 2 \mathrm{C} \% 20$ titanium $\% 20$ dioxide $\% 20$ (TiO2,oxide $\% 20$ must $\% 20$ still\%20be\%20conducted. (Accessed on $22^{\text {nd }}$ February 2021.)

[22]Jamkhande PG, Ghule NW, Bamer AH, Kalaskar MG. Metal nanoparticles synthesis: An overview on methods of preparation, advantages and disadvantages, and applications. Journal of Drug Delivery Science and Technology. 2019 Oct 1;53:101174. https://doi.org/10.1016/j.jddst.2019.101174

[23]Zhang D, Ma XL, Gu Y, Huang H, Zhang GW. Green Synthesis of Metallic Nanoparticles and Their Potential Applications to Treat Cancer. Frontiers in Chemistry. 2020;8. https://dx.doi.org/10.3389\%2Ffchem.2020.00799

[24]Sugar chemistry. Available from: https://opentextbc.ca/ingredients/chapter/sugar-chemistry. (accessed on $30^{\text {th }}$ JANUARY ,2021)

[25]Iqbal P, Preece JA, Mendes PM. Nanotechnology: The "Top-Down" and "Bottom-Up" Approaches. Supramolecular chemistry: from molecules to nanomaterials. 2012 Mar 15.

[26]Charitidis CA, Georgiou P, Koklioti MA, Trompeta AF, Markakis V. Manufacturing nanomaterials: from research to industry Manufacturing Review. 2014;1:11. https://doi.org/10.1051/mfreview/2014009

[27]Tsuzuki T. Commercial scale production of inorganic nanoparticles. International journal of nanotechnology. 2009 Jan 1;6(5-6):567-78. https://dx.doi.org/10.1504/IJNT.2009.024647

[28] Gahlawat G, Choudhury AR. A review on the biosynthesis of metal and metal salt nanoparticles by microbes. RSC advances 2019;9(23):12944-67. https://doi.org/10.1039/C8RA10483B

[29] Narayanan KB, Sakthivel N. Biological synthesis of metal nanoparticles by microbes. Advances in colloid and interface science. $\quad 2010 \quad$ Apr $22 ; 156(1-2): 1-3$ https://doi.org/10.1016/j.cis.2010.02.001

[30]Yadi M, Mostafavi E, Saleh B, Davaran S, Aliyeva I, Khalilov R, Nikzamir M, Nikzamir N, Akbarzadeh A, Panahi Y, Milani M Current developments in green synthesis of metallic nanoparticles using plant extracts: a review. Artificial cells, nanomedicine, and biotechnology. $2018 \quad$ Nov 12;46(sup3):S336-43. https://doi.org/10.1080/21691401.2018.1492931

[31] Singh J, Dutta T, Kim KH, Rawat M, Samddar P, Kumar P. 'Green'synthesis of metals and their oxide nanoparticles: applications for environmental remediation. Journal of nanobiotechnology. $2018 \quad$ Dec;16(1):1-24 https://doi.org/10.1186/s12951-018-0408-4

[32] Gour A, Jain NK. Advances in green synthesis of nanoparticles. Artificial cells, nanomedicine, and biotechnology. 2019 Dec 4;47(1):844-51.

https://doi.org/10.1080/21691401.2019.1577878

[33] Salunke BK, Sawant SS, Lee SI, Kim BS. Microorganisms as efficient biosystem for the synthesis of metal nanoparticles: current scenario and future possibilities. World Journal of Microbiology and Biotechnology. 2016 May 1;32(5):88 https://doi.org/10.1007/s11274-016-2044-1

[34]Iravani S. Bacteria in nanoparticle synthesis: current status and future prospects. International scholarly research notices. 2014;2014. https://doi.org/10.1155/2014/359316

[35] Yadav A, Kon K, Kratosova G, Duran N, Ingle AP, Rai M. Fungi as an efficient mycosystem for the synthesis of metal nanoparticles: progress and key aspects of research. Biotechnology letters. 2015 Nov;37(11):2099-120. https://doi.org/10.1007/s10529-015 1901-6
Journal of Drug Delivery \& Therapeutics. 2021; 11(6):304-314

[36] Li J, Ma G, Liu H, Liu H. Yeast cells carrying metal nanoparticles. Materials Chemistry and Physics. 2018 Mar 1;207:373-9. https://doi.org/10.1016/j.matchemphys.2018.01.001

[37] Manimaran M, Kannabiran K. Actinomycetes-mediated biogenic synthesis of metal and metal oxide nanoparticles: progress and challenges. Letters in applied microbiology. 2017 Jun;64(6):401-8. https://doi.org/10.1111/lam.12730

[38] Siddiqi KS, Husen A. Fabrication of metal and metal oxide nanoparticles by algae and their toxic effects. Nanoscale research letters. 2016 Dec;11(1):1-1. https://doi.org/10.1186/s11671016-1580-9

[39] Ishak NM, Kamarudin SK, Timmiati SN. Green synthesis of metal and metal oxide nanoparticles via plant extracts: an overview. Materials Research Express. 2019 Oct 4;6(11):112004. https://doi.org/10.1088/2053-1591/ab4458

[40] Tangahu BV, Sheikh Abdullah SR, Basri H, Idris M, Anuar N, Mukhlisin M. A review on heavy metals (As, $\mathrm{Pb}$, and $\mathrm{Hg}$ ) uptake by plants through phytoremediation. International Journal of Chemical Engineering. 2011 Oct 1;2011. https://doi.org/10.1155/2011/939161

[41] Marchiol L. Synthesis of metal nanoparticles in living plants. Italian Journal of Agronomy. 2012 Aug 6:e37http://dx.doi.org/10.4081/ija.2012.e37

[42]El ShafeyAM. Green synthesis of metal and metal oxide nanoparticles from plant leaf extracts and their applications: A review. Green Processing and Synthesis. 2020 Jun 18;9(1):304-39. https://doi.org/10.1515/gps-2020-0031

[43] Silva LP, Reis IG, Bonatto CC. Green synthesis of metal nanoparticles by plants: current trends and challenges. InGreen processes for Nanotechnology 2015 (pp. 259-275). Springer, Cham. https://doi.org/10.1007/978-3-319-15461-9_9

[44]Dauthal P, Mukhopadhyay M. Noble metal nanoparticles: plantmediated synthesis, mechanistic aspects of synthesis, and applications. Industrial \& Engineering Chemistry Research. 2016 Sep 14;55(36):9557-77.

[45]Jadoun S, Arif R, Jangid NK, Meena RK. Green synthesis of nanoparticles using plant extracts: a review. Environmental Chemistry Letters. 2020 Aug 13:1-20. https://doi.org/10.1007/s10311-020-01074-x

[46] Kharissova OV, Kharisov BI, Oliva González CM, Méndez YP, López I. Greener synthesis of chemical compounds and materials. Royal Society open science. 2019 Nov 6;6(11):191378. https://doi.org/10.1098/rsos.191378

[47]Rafique M, Sadaf I, Rafique MS, Tahir MB. A review on green synthesis of silver nanoparticles and their applications. Artificial cells, nanomedicine, and biotechnology. 2017 Oct 3;45(7):127291. https://doi.org/10.1080/21691401.2016.1241792

[48] Roy P, Das B, Mohanty A, Mohapatra S. Green synthesis of silver nanoparticles using Azadirachta indica leaf extract and its antimicrobial study. Applied Nanoscience. 2017 Nov;7(8):843-50. https://doi.org/10.1007/s13204-017-0621-8

[49] Rautela A, Rani J, Das MD. Green synthesis of silver nanoparticles from Tectona grandis seeds extract: characterization and mechanism of antimicrobial action on different microorganisms. Journal of Analytical Science and Technology. 2019 Dec;10(1):1-0. https://doi.org/10.1186/s40543-018-0163-z

[50] Padalia H, Moteriya P, Chanda S. Green synthesis of silver nanoparticles from marigold flower and its synergistic antimicrobial potential. Arabian Journal of Chemistry. 2015 Sep 1;8(5):732-41. https://doi.org/10.1016/j.arabjc.2014.11.015

[51] Pethakamsetty L, Kothapenta K, Nammi HR, Ruddaraju LK, Kollu P, Yoon SG, Pammi SV. Green synthesis, characterization and antimicrobial activity of silver nanoparticles using methanolic root extracts of Diospyros sylvatica. Journal of Environmental Sciences. $\quad 2017 \quad$ May $\quad 1 ; 55: 157-63$. https://doi.org/10.1016/j.jes.2016.04.027

[52]Yugandhar P, Haribabu R, Savithramma N. Synthesis, characterization and antimicrobial properties of greensynthesised silver nanoparticles from stem bark extract of 
Syzygium alternifolium (Wt.) Walp. 3 Biotech. 2015 Dec;5(6):1031-9. https://doi.org/10.1007/s13205-015-0307-4

[53]Ghaffari-Moghaddam M, Hadi-Dabanlou R. Plant mediated green synthesis and antibacterial activity of silver nanoparticles using Crataegus douglasii fruit extract. Journal of Industrial and Engineering Chemistry. 2014 Mar 25;20(2):739-44. https://doi.org/10.1016/j.jiec.2013.09.005

[54]Kim TY, Cha SH, Cho S, Park Y. Tannic acid-mediated green synthesis of antibacterial silver nanoparticles. Archives of pharmacal research. 2016 Apr 1;39(4):465-73. https://doi.org/10.1007/s12272-016-0718-8

[55]Ahmad T, Bustam MA, Irfan M, Moniruzzaman M, Asghar HM, Bhattacharjee S. Mechanistic investigation of phytochemicals involved in green synthesis of gold nanoparticles using aqueous Elaeis guineensis leaves extract: Role of phenolic compounds and flavonoids. Biotechnology and applied biochemistry. 2019 Jul;66(4):698-708. https://doi.org/10.1002/bab.1787

[56]Banerjee P, Satapathy M, Mukhopahayay A, Das P. Leaf extract mediated green synthesis of silver nanoparticles from widely available Indian plants: synthesis, characterization, antimicrobial property and toxicity analysis. Bioresources and Bioprocessing. 2014 Dec;1(1):1-0. https://doi.org/10.1186/s40643-014-0003-y

[57]Vijayaraj R, Kumar KN, Mani P, Senthil J, Kumar GD, Jayaseelan T. Green synthesis of silver nanoparticles from ethanolic seed extract of Acranythesaspera (Linn.) and its anti-inflammatory activities. Int J Pharm Ther. 2016;7:42-8. https://doi.org/10.2174/1389201021666200107115849

[58] Gavamukulya Y, Maina EN, Meroka AM, Madivoli ES, El-Shemy HA, Wamunyokoli F, Magoma G. Green synthesis and characterization of highly stable silver nanoparticles from ethanolic extracts of fruits of Annona muricata. Journal of Inorganic and Organometallic Polymers and Materials. 2020 Apr;30(4):1231-42. https://doi.org/10.1007/s10904-019-01262-5

[59]Petla RK, Vivekanandhan S, Misra M, Mohanty AK, Satyanarayana N. Soybean (Glycine max) leaf extract based green synthesis of palladium http://dx.doi.org/10.4236/jbnb.2012.31003

nanoparticles.

[60] Mason C, Vivekanandhan S, Misra M, Mohanty AK. Switch grass (Panicum virgatum) extract mediated green synthesis of silver nanoparticles. World Journal of Nano Science and Engineering. 2012 Jun 1;2(2):47.

[61]Rajabi HR, Sajadiasl F, Karimi H, Alvand ZM. Green synthesis of zinc sulfide nanophotocatalysts using aqueous extract of FicusJohannis plant for efficient photodegradation of some pollutants. Journal of Materials Research and Technology. 2020 Nov

$1 ; 9(6): 15638-47$ https://doi.org/10.1016/j.jmrt.2020.11.017

[62]Balasubramani G, Ramkumar R, Krishnaveni N, Pazhanimuthu A, Natarajan T, Sowmiya R, Perumal P. Structural characterization, antioxidant and anticancer properties of gold nanoparticles synthesized from leaf extract (decoction) of Antigononleptopus Hook. \&Arn. Journal of Trace Elements in Medicine and Biology. 2015 Apr 1;30:83-9. https://doi.org/10.1016/j.jtemb.2014.11.001

[63] Selim YA, Azb MA, Ragab I, Abd El-Azim MH. Green synthesis of zinc oxide nanoparticles using aqueous extract of Deverratortuosa and their cytotoxic activities. Scientific reports. 2020 Feb 26;10(1):1-9. https://doi.org/10.1038/s41598-020-60541-1

[64]Ahmed S, Saifullah, Ahmad M, Swami BL, Ikram S. Green synthesis of silver nanoparticles using Azadirachta indica aqueous leaf extract. Journal of radiation research and applied sciences. 2016 Jan 1;9(1):1-7. https://doi.org/10.1007/s13204-017-0621-8

[65]Aritonang HF, Koleangan H, Wuntu AD. Synthesis of silver nanoparticles using aqueous extract of medicinal plants'(Impatiens balsamina and Lantana camara) fresh leaves and analysis of antimicrobial activity. International journal of $\begin{array}{llll}\text { microbiology. } & 2019 & \text { Jul } & \text { 1;2019. }\end{array}$ https://doi.org/10.1155/2019/8642303

[66] Shnoudeh AJ, Hamad I, Abdo RW, Qadumii L, Jaber AY, Surchi HS, Alkelany SZ. Synthesis, Characterization, and Applications of Metal
Journal of Drug Delivery \& Therapeutics. 2021; 11(6):304-314

Nanoparticles. InBiomaterials and Bionanotechnology 2019 Jan 1 (pp. 527-612). Academic Press. https://doi.org/10.1016/B978-012-814427-5.00015-9

[67]Rao K, Roome T, Aziz S, Razzak A, Abbas G, Imran M, Jabri T, Gul J, Hussain M, Sikandar B, Sharafat S. Bergenin loaded gum xanthan stabilized silver nanoparticles suppress synovial inflammation through modulation of the immune response and oxidative stress in adjuvant induced arthritic rats. Journal of Materials Chemistry B. 2018;6(27):4486-501. https://doi.org/10.1039/C8TB00672E

[68] Wang L, Xu J, Yan Y, Liu H, Karunakaran T, Li F. Green synthesis of gold nanoparticles from Scutellaria barbata and its anticancer activity in pancreatic cancer cell (PANC-1). Artificial cells, nanomedicine, and biotechnology. 2019 Dec 4;47(1):1617-27. https://doi.org/10.1080/21691401.2019.1594862

[69]Xin Lee K, Shameli K, Miyake M, Kuwano N, Bt Ahmad Khairudin NB, Bt Mohamad SE, Yew YP. Green synthesis of gold nanoparticles using aqueous extract of Garcinia mangostana fruit peels. Journal of Nanomaterials. 2016 Sep 1;2016. https://doi.org/10.1155/2016/8489094

[70]Wu S, Rajeshkumar S, Madasamy M, Mahendran V. Green synthesis of copper nanoparticles using Cissus vitiginea and its antioxidant and antibacterial activity against urinary tract infection pathogens. Artificial Cells, Nanomedicine, and Biotechnology. $2020 \quad$ Jan 1;48(1):1153-8 https://doi.org/10.1080/21691401.2020.1817053

[71] Khandel P, Yadaw RK, Soni DK, Kanwar L, Shahi SK. Biogenesis of metal nanoparticles and their pharmacological applications: present status and application prospects. Journal of Nanostructure in $\quad$ Chemistry. $2018 \quad$ Sep;8(3):217-54 https://doi.org/10.1007/s40097-018-0267-4

[72] Kuppusamy P, Yusoff MM, Maniam GP, Govindan N. Biosynthesis of metallic nanoparticles using plant derivatives and their new avenues in pharmacological applications-An updated report. Saudi Pharmaceutical Journal. 2016 Jul 1;24(4):473-84. https://doi.org/10.1016/j.jsps.2014.11.013

[73]Jeevanandam J, Chan YS, Danquah MK. Biosynthesis of metal and metal oxide nanoparticles. ChemBioEng Reviews. 2016 Apr;3(2):55-67. https://doi.org/10.1002/cben.201500018

[74]Chokkareddy R, Redhi GG. Green synthesis of metal nanoparticles and its reaction mechanisms. Green Metal Nanoparticles: Synthesis, Characterization and Their Application; Kanchi, S.,

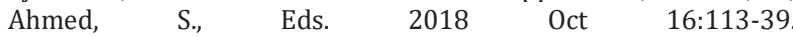
https://doi.org/10.1002/9781119418900.ch4

[75]Malik P, Shankar R, Malik V, Sharma N, Mukherjee TK. Green chemistry based benign routes for nanoparticle synthesis. Journal of Nanoparticles. 2014;2014. https://doi.org/10.1155/2014/302429

[76] Kulkarni VD, Kulkarni PS. Green synthesis of copper nanoparticles using Ocimum sanctum leaf extract. Int J Chem Stud. 2013;1(3):14

[77]Tahir K, Nazir S, Ahmad A, Li B, Khan AU, Khan ZU, Khan FU, Khan QU, Khan A, Rahman AU. Facile and green synthesis of phytochemicals capped platinum nanoparticles and in vitro their superior antibacterial activity. Journal of Photochemistry and Photobiology B: Biology. 2017 Jan 1;166:246-51. https://doi.org/10.1016/j.jphotobiol.2016.12.016

[78]Banu KS, Cathrine L. General techniques involved in phytochemical analysis. International Journal of Advanced Research in Chemical Science. 2015 Apr;2(4):25-32.

[79]Visweswari G, Christopher R, Rajendra W. Phytochemical screening of active secondary metabolites present in Withaniasomnifera root: role in traditional medicine. International journal of pharmaceutical sciences and research. 2013 Jul 1;4(7):2770. 10.13040/IJPSR.0975-8232.4(7).2770-76

[80] Paul S, Dhinakaran I, Mathiyazhagan K, Raja M, Sasikumar CS, Varghese JC. Preparation of nanogel incorporated with silver nanoparticles synthesized from pongamiapinnata. L root. Int J Sci Res Knowl. 2015;3:314-25. 
[81]Ramaswamy M, Solaimuthu C, Duraikannu S. Antiarthritic activity of synthesized silver nanoparticles from aqueous extract of Moringa concanensis Nimmo leaves against FCA induced rheumatic arthritis in rats. Journal of Drug Delivery and Therapeutics. 2019 May 15;9(3):66-75.

[82]Kiranmai M. Biological and non-biological synthesis of metallic nanoparticles: Scope for current pharmaceutical research. Indian Journal of Pharmaceutical Sciences. 2017 Oct 31;79(4):501-12 10.4172/pharmaceutical-sciences.1000256

[83] Shah M, Fawcett D, Sharma S, Tripathy SK, Poinern GE. Green synthesis of metallic nanoparticles via biological entities. Materials. $2015 \quad$ Nov;8(11):7278-308. https://doi.org/10.3390/ma8115377

[84] Parida UK, Das S, Jena PK, Rout N, Bindhani BK. Plant mediated green synthesis of metallic nanoparticles: Challenges and opportunities. InFabrication and self-assembly o nanobiomaterials 2016 Jan 1 (pp. 149-177). William Andrew Publishing. $\quad$ https://doi.org/10.1016/B978-0-323-41533 $0.00006-4$

[85]Patra JK, Baek KH. Green nanobiotechnology: factors affecting synthesis and characterization techniques. Journal of Nanomaterials. $\quad 2014 \quad$ Jan $1 ; 2014$ https://doi.org/10.1155/2014/417305

[86]Altemimi A, Lakhssassi N, Baharlouei A, Watson DG, Lightfoot DA Phytochemicals: Extraction, isolation, and identification of bioactive compounds from plant extracts. Plants. 2017 Dec;6(4):42. https://dx.doi.org/10.3390\%2Fplants6040042

[87]Hariram M, Vivekanandhan S. Phytochemical process for the functionalization of materials with metal nanoparticles: current trends and future perspectives. ChemistrySelect. 2018 Dec 28;3(48):13561-85. https://doi.org/10.1002/slct.201802748

[88]Akhtar MS, Panwar J, Yun YS. Biogenic synthesis of metallic nanoparticles by plant extracts. ACS Sustainable Chemistry \& Engineering. 2013 Jun 3;1(6):591-602. https://doi.org/10.22159/ajpcr.2019.v12i7.33211

[89] Latif MS, Abbas S, Kormin F, Mustafa MK. Green synthesis of plantmediated metal nanoparticles: The role of polyphenols. Asian J $\begin{array}{lll}\text { Pharmaceut. } & \text { Clin. } & \text { Res. }\end{array}$ https://doi.org/10.22159/ajpcr.2019.v12i7.33211

[90]Mathur M. Properties of phtyo-reducing agents utilize for production of nano-particles, existing knowledge and gaps. Int Pure ApplBiosci. 2014;2(2):113-30.

[91]Makarov VV, Love AJ, Sinitsyna OV, Makarova SS, Yaminsky IV Taliansky ME, Kalinina NO. “Green” nanotechnologies: synthesis of metal nanoparticles using plants. ActaNaturae (англоязычнаяверсия). 2014;6(1 https://www.ncbi.nlm.nih.gov/pubmed/24772325

[92]Lade BD, Shanware AS. Phytonanofabrication: methodology and factors affecting biosynthesis of nanoparticles InSmartNanosystems for Biomedicine, Optoelectronics and Catalysis 2020 Jan 21. IntechOpen.

[93]Vijayaraghavan K, Ashokkumar T. Plant-mediated biosynthesis of metallic nanoparticles: a review of literature, factors affecting synthesis, characterization techniques and applications. Journal of environmental chemical engineering. 2017 Oct 1;5(5):4866-83 https://doi.org/10.1016/j.jece.2017.09.026

[94]Anigol LB, Charantimath JS, Gurubasavaraj PM. Effect of concentration and ph on the size of silver nanoparticles synthesized by green chemistry. Org. Med. Chem. Int. J. 2017;3:1 5 .

[95]Singh AK, Srivastava ON. One-step green synthesis of gold nanoparticles using black cardamom and effect of $\mathrm{pH}$ on its synthesis. Nanoscale research letters. 2015 Dec 1;10(1):353. https://doi.org/10.1186/s11671-015-1055-4

[96]Rao B, Tang RC. Green synthesis of silver nanoparticles with antibacterial activities using aqueous Eriobotrya japonica lea extract. Advances in natural sciences: Nanoscience and nanotechnology. $2017 \quad$ Mar 2;8(1):015014 https://doi.org/10.1088/2043-6254/aa5983
[97] Kredy HM. The effect of $\mathrm{pH}$, temperature on the green synthesis and biochemical activities of silver nanoparticles from Lawsonia inermis extract. Journal of Pharmaceutical Sciences and Research 2018 Aug 1;10(8):2022-6.

[98] Seifipour R, Nozari M, Pishkar L. Green synthesis of silver nanoparticles using Tragopo goncollinus leaf extract and study of their antibacterial effects. Journal of Inorganic and Organometallic Polymers and Materials. 2020 Jan 11:1-1. https://doi.org/10.1007/s10904-020-01441-9

[99]Ahmad T, Irfan M, Bustam MA, Bhattacharjee S. Effect of reaction time on green synthesis of gold nanoparticles by using aqueous extract of Elaise guineensis (oil palm leaves). Procedia engineering. $2016 \quad$ Jan 1;148:467-72. https://doi.org/10.1016/j.proeng.2016.06.465

[100] Ahmed S, Ahmad M, Swami BL, Ikram S. A review on plants extract mediated synthesis of silver nanoparticles for antimicrobial applications: a green expertise. Journal of advanced research. 2016 Jan $1 ; 7(1): 17-28$ https://doi.org/10.1016/j.jare.2015.02.007

[101] Patanjali Research Institute [online] available from :https://www.patanjaliresearchinstitute.com/chemistry.php (Accessed on 17th February, 2021)

[102] Chen J, Li Y, Fang G, Cao Z, Shang Y, Alfarraj S, Alharbi SA, Li J, Yang S, Duan X. Green synthesis, characterization, cytotoxicity, antioxidant, and anti-human ovarian cancer activities of Curcumae kwangsiensis leaf aqueous extract green-synthesized gold nanoparticles. Arabian Journal of Chemistry. 2021 Mar 1;14(3):103000. https://doi.org/10.1016/j.arabjc.2021.103000

[103] Chang Y, Zheng C, Chinnathambi A, Alahmadi TA, Alharbi SA. Cytotoxicity, anti-acute leukemia, and antioxidant properties of gold nanoparticles green-synthesized using Cannabis sativa L leaf aqueous extract. Arabian Journal of Chemistry. 2021 Feb 11:103060. https://doi.org/10.1016/j.arabjc.2021.103060

[104] Liu Q, Wu F, Chen Y, Alrashood ST, Alharbi SA. Anti-human colon cancer properties of a novel chemotherapeutic supplement formulated by gold nanoparticles containing Allium sativum L. leaf aqueous extract and investigation of its cytotoxicity and antioxidant activities. Arabian Journal of Chemistry. 2021 Feb 2:103039. https://doi.org/10.1016/j.arabjc.2021.103039

[105] Muniyappan N, Pandeeswaran M, Amalraj A. Green synthesis of gold nanoparticles using Curcuma pseudomontana isolated curcumin: Its characterization, antimicrobial, antioxidant and anti-inflammatory activities. Environmental Chemistry and Ecotoxicology. $2021 \quad 30$ https://doi.org/10.1016/j.enceco.2021.01.002

[106] Li S, Al-Misned FA, El-Serehy HA, Yang L. Green synthesis of gold nanoparticles using aqueous extract of MenthaLongifolia leaf and investigation of its anti-human breast carcinoma properties in the in vitro condition. Arabian Journal of Chemistry. 2021 Feb 1;14(2):102931. https://doi.org/10.1016/j.arabjc.2020.102931

[107] Alkhalaf MI, Hussein RH, Hamza A. Green synthesis of silver nanoparticles by Nigella sativa extract alleviates diabetic neuropathy through anti-inflammatory and antioxidant effects. Saudi Journal of Biological Sciences. 2020 Sep 1;27(9):2410-9. https://doi.org/10.1016/j.sjbs.2020.05.005

[108] Dhar SA, Chowdhury RA, Das S, Nahian MK, Islam D, Gafur MA. Plant-mediated green synthesis and characterization of silver nanoparticles using Phyllanthus emblica fruit extract. Materials Today: $\quad$ Proceedings. $2021 \quad$ Jan 22 https://doi.org/10.1016/j.matpr.2020.12.222

[109] Sharma R. Synthesis of Terminalia bellirica fruit extract mediated silver nanoparticles and application in photocatalytic degradation of wastewater from textile industries. Materials Today: $\quad$ Proceedings. $2021 \quad$ Feb 19 https://doi.org/10.1016/j.matpr.2020.12.118

[110] Filip GA, Florea A, Olteanu D, Clichici S, David L, Moldovan B, Cenariu M, Scrobota I, Potara M, Baldea I. Biosynthesis of silver nanoparticles using Sambucus nigra L. fruit extract for targeting cell death in oral dysplastic cells. Materials Science and Engineering: $\quad$ C. $2021 \quad$ Feb $15: 111974$ https://doi.org/10.1016/j.msec.2021.111974 
[111] Wang Y, Chinnathambi A, Nasif O, Alharbi SA. Green synthesis and chemical characterization of a novel anti-human pancreatic cancer supplement by silver nanoparticles containing Zingiber officinale leaf aqueous extract. Arabian Journal of Chemistry. $\quad 2021 \quad$ Feb $21: 103081$ https://doi.org/10.1016/j.arabjc.2021.103081

[112] Jahan I, Erci F, Isildak I. Facile microwave-mediated green synthesis of non-toxic copper nanoparticles using Citrus sinensis aqueous fruit extract and their antibacterial potentials. Journal of Drug Delivery Science and Technology. 2020 Oct 29:102172. https://doi.org/10.1016/j.jddst.2020.102172

[113] Sathiyavimal S, Vasantharaj S, Veeramani V, Saravanan M, Rajalakshmi G, Kaliannan T, Al-Misned FA, Pugazhendhi A. Green chemistry route of biosynthesized copper oxide nanoparticles using Psidiumguajava leaf extract and their antibacterial activity and effective removal of industrial dyes. Journal of Environmental Chemical Engineering. 2021 Jan 6:105033. https://doi.org/10.1016/j.jece.2021.105033

[114] Dou L, Zhang X, Zangeneh MM, Zhang Y. Efficient biogenesis of Cu2O nanoparticles using extract of Camellia sinensis leaf: Evaluation of catalytic, cytotoxicity, antioxidant, and anti-human ovarian cancer properties. Bioorganic Chemistry. 2021 Jan 1;106:104468. https://doi.org/10.1016/j.bioorg.2020.104468

[115] Asghar MA, Zahir E, Asghar MA, Iqbal J, Rehman AA. Facile, one-pot biosynthesis and characterization of iron, copper and silver nanoparticles using Syzygiumcumini leaf extract: As an effective antimicrobial and aflatoxin B1 adsorption agents. PloS one. $2020 \quad$ Jul 2;15(7):e0234964. https://doi.org/10.1371/journal.pone.0234964

[116] Iliger KS, Sofi TA, Bhat NA, Ahanger FA, Sekhar JC, Elhendi AZ, Al-Huqail AA, Khan F. Copper nanoparticles: Green synthesis and managing fruit rot disease of chilli caused by Colletotrichum capsici. Saudi Journal of Biological Sciences. 2021 Feb 1;28(2):1477-86. https://doi.org/10.1016/j.sjbs.2020.12.003

[117] Ekennia A, Uduagwu D, Olowu O, Nwanji O, Oje O, Daniel B, Mgbii S, Emma-Uba C. Biosynthesis of zinc oxide nanoparticles using leaf extracts of Alchornealaxiflora and its tyrosinase inhibition and catalytic studies. Micron. 2021 Feb 1;141:102964. https://doi.org/10.1016/j.micron.2020.102964

[118] Chinnathambi A, Alahmadi TA. Zinc nanoparticles greensynthesized by Alhagimaurorum leaf aqueous extract: Chemical characterization and cytotoxicity, antioxidant, and antiosteosarcoma effects. Arabian Journal of Chemistry. 2021 Feb 22:103083. https://doi.org/10.1016/j.arabjc.2021.103083

[119] Park JK, Rupa EJ, Arif MH, Li JF, Anandapadmanaban G, Kang JP, Kim M, Ahn JC, Akter R, Yang DC, Kang SC. Synthesis of zinc oxide nanoparticles from Gynostemmapentaphyllum extracts and assessment of photocatalytic properties through malachite green dye decolorization under UV illumination-A green approach. Optik. 2021 Jan 5:166249. https://doi.org/10.1016/j.ijleo.2020.166249

[120] Ghaedi M, Naghiha R, Jannesar R, Mirtamizdoust B. Antibacterial and antifungal activity of flower extracts of Urticadioica, Chamaemelumnobile and Salvia officinalis: Effects of $\mathrm{Zn}[\mathrm{OH}] 2$ nanoparticles and Hp-2-minh on their property. Journal of Industrial and Engineering Chemistry. 2015 Dec 25;32:353-9. https://doi.org/10.1016/j.jiec.2015.09.007

[121] Umamaheswari A, Prabu SL, John SA, Puratchikody A. Green synthesis of Zinc Oxide Nanoparticles using leaf extracts of Raphanussativus L var. and evaluation of their anticancer property in A549 cell lines. Biotechnology Reports. 2021 Feb 5:e00595. https://doi.org/10.1016/j.btre.2021.e00595

[122] Korde P, Ghotekar S, Pagar T, Pansambal S, Oza R, Mane D. Plant extract assisted eco-benevolent synthesis of selenium nanoparticles-a review on plant parts involved, characterization and their recent applications. Journal of Chemical Reviews. 2020 Apr 23:157-68. https://dx.doi.org/10.22034/jcr.2020.106601

[123] Mulla NA, Otari SV, Bohara RA, Yadav HM, Pawar SH. Rapid and size-controlled biosynthesis of cytocompatible selenium nanoparticles by Azadirachtaindica leaves extract for antibacterial activity. Materials Letters. 2020 Apr 1;264:127353. https://doi.org/10.1016/j.matlet.2020.127353

[124] Kirdat PN, Dandge PB, Hagwane RM, Nikam AS, Mahadik SP, Jirange ST. Synthesis and characterization of ginger (Z. officinale) extract mediated iron oxide nanoparticles and its antibacterial activity. Materials Today: Proceedings. 2020 Dec 30. https://doi.org/10.1016/j.matpr.2020.11.422

[125] Ardakani LS, Alimardani V, Tamaddon AM, Amani AM, Taghizadeh S. Green synthesis of iron-based nanoparticles using Chlorophytumcomosum leaf extract: methyl orange dye degradation and antimicrobial properties. Heliyon. 2021 Feb 1;7(2):e06159. https://doi.org/10.1016/j.heliyon.2021.e06159

[126] Biswas A, Vanlalveni C, Lalfakzuala R, Nath S, Rokhum L. Mikaniamikrantha leaf extract mediated biogenic synthesis of magnetic iron oxide nanoparticles: Characterization and its antimicrobial activity study. Materials Today: Proceedings. 2021 Feb 16. https://doi.org/10.26434/chemrxiv.13203887.v1

[127] Yetisgin AA, Cetinel S, Zuvin M, Kosar A, Kutlu O. Therapeutic nanoparticles and their targeted delivery applications. Molecules. 2020 Jan;25(9):2193. https://doi.org/10.3390/molecules25092193

[128] Sood R, Chopra DS. Regulatory approval of silver nanoparticles. Applied Clinical Research, Clinical Trials and Regulatory Affairs. $2018 \quad$ Aug 1;5(2):74-9. https://doi.org/10.2174/2213476X05666180614121601 